\title{
High genetic variability of vagrant polar bears illustrates importance of population connectivity in fragmented sea ice habitats
}

\author{
V. E. Kutschera ${ }^{1,2}$, C. Frosch ${ }^{3}$, A. Janke ${ }^{1,4}$, K. Skírnisson ${ }^{5}$, T. Bidon ${ }^{1}$, N. Lecomte ${ }^{6,7}$, S. R. Fain ${ }^{8}$, \\ H. G. Eiken ${ }^{9}$, S. B. Hagen ${ }^{9}$, U. Arnason ${ }^{10}$, K. L. Laidre ${ }^{11}$, C. Nowak $^{3}$ \& F. Hailer ${ }^{1,12}$ \\ 1 Senckenberg Biodiversity and Climate Research Centre (BiK-F), Senckenberg Gesellschaft für Naturforschung, Frankfurt am Main, \\ Germany \\ 2 Department of Evolutionary Biology, Evolutionary Biology Centre, Uppsala University, Uppsala, Sweden \\ 3 Conservation Genetics Group, Senckenberg Research Institute and Natural History Museum Frankfurt, Gelnhausen, Germany \\ 4 Institute for Ecology, Evolution and Diversity, Goethe University Frankfurt, Frankfurt am Main, Germany \\ 5 Institute for Experimental Pathology, Keldur, University of Iceland, Reykjavík, Iceland \\ 6 Canada Research Chair in Polar and Boreal Ecology, Department of Biology, University of Moncton, Moncton, NB, Canada \\ 7 Government of Nunavut, Igloolik, NU, Canada \\ 8 National Fish and Wildlife Forensic Laboratory, Ashland, OR, USA \\ 9 NIBIO, Norwegian Institute for Bioeconomy Research, Svanvik, Norway \\ 10 Faculty of Medicine, University of Lund, Lund, Sweden \\ 11 Applied Physics Laboratory, Polar Science Center, University of Washington, Seattle, WA, USA \\ 12 School of Biosciences, Cardiff University, Cardiff, Wales, UK
}

\section{Keywords}

climate change; dispersal; genetic variability; habitat fragmentation; inbreeding; Arctic sea ice; Ursus maritimus; polar bear.

\section{Correspondence \\ Verena E. Kutschera, Biodiversity and Climate Research Centre (BiK-F), Senckenberg Gesellschaft für Naturforschung, Senckenberganlage 25, 60325 Frankfurt am Main, Germany; Department of Evolutionary Biology, Evolutionary Biology Centre, Uppsala University, SE-752 36 Uppsala, Sweden. Email: v.kutschera@gmx.net Frank Hailer, Biodiversity and Climate Research Centre (BiK-F), Senckenberg Gesellschaft für Naturforschung, Senckenberganlage 25, 60325 Frankfurt am Main, Germany; Cardiff University, School of Biosciences, Cardiff CF10 3AX, UK. Email: HailerF@cardiff.ac.uk \\ Editor: Jeff Johnson \\ Associate Editor: Tammy Steeves}

Received 20 May 2015; accepted 10 November 2015

\begin{abstract}
Projections by the Intergovernmental Panel on Climate Change (IPCC) and sea ice forecasts suggest that Arctic sea ice will decline markedly in coming decades. Expected effects on the entire ecosystem include a contraction of suitable polar bear habitat into one or few refugia. Such large-scale habitat decline and fragmentation could lead to reduced genetic diversity. Here we compare genetic variability of four vagrant polar bears that reached Iceland with that in recognized subpopulations from across the range, examining 23 autosomal microsatellites, mitochondrial control region sequences and Y-chromosomal markers. The vagrants' genotypes grouped with different genetic clusters and showed similar genetic variability at autosomal microsatellites (expected heterozygosity, allelic richness, and individual heterozygosity) as individuals in recognized subpopulations. Each vagrant carried a different mitochondrial haplotype. A likely route for polar bears to reach Iceland is via Fram Strait, a major gateway for the physical exportation of sea ice from the Arctic basin. Vagrant polar bears on Iceland likely originated from more than one recognized subpopulation, and may have been caught in sea ice export during long-distance movements to the East Greenland area. Although their potentially diverse geographic origins might suggest that these vagrants encompass much higher genetic variability than vagrants or dispersers in other regions, the four Icelandic vagrants encompassed similar genetic variability as any four randomly picked individuals from a single subpopulation or from the entire sample. We suggest that this is a consequence of the low overall genetic variability and weak range-wide genetic structuring of polar bears - few dispersers can represent a large portion of the species' gene pool. As predicted by theory and our demographic simulations, continued gene flow will be necessary to counteract loss of genetic variability in increasingly fragmented Arctic habitats. Similar considerations will be important in the management of other taxa that utilize sea ice habitats.
\end{abstract}




\section{Introduction}

Many species persist in landscapes where patches suitable for foraging or reproduction are situated in a matrix of nonsuitable habitat (Hanski \& Gaggiotti, 2004). Highly mobile species are more likely to disperse among habitat patches, facilitating gene flow and thereby counteracting the loss of genetic variability in individual demes (e.g. Hamrick \& Godt, 1996; Keyghobadi, 2007). However, connectivity in fragmented habitats can be reduced by numerous anthropogenic factors, such as extinction of some patches, reduced area of habitat fragments, or decreased permeability of the matrix (Gascon et al., 1999; Fischer \& Lindenmayer, 2007). Increased habitat fragmentation along with population size reductions can thus negatively impact demographic stability in individual patches, and reduce the genetic variability of the entire species (Baum et al., 2004; Hanski \& Gaggiotti, 2004; Fischer \& Lindenmayer, 2007).

Several ice-dependent mammal specialists such as polar bears Ursus maritimus, Arctic foxes Vulpes lagopus and ringed seals Pusa hispida utilize the Arctic sea ice for foraging, reproduction and dispersal (e.g. Amstrup, 2003; Geffen et al., 2007; Kelly et al., 2010; Norén et al., 2011). Arctic sea ice also facilitates dispersal of several terrestrial taxa, such as gray wolves Canis lupus in the Canadian Arctic archipelago (Carmichael et al., 2008). Sea ice is currently declining, and forecasts suggest an ice-free Arctic ocean dur- ing summers in the next few decades (Overland \& Wang, 2013; IPCC 2014; Laidre et al., 2015b). However, current and projected sea ice conditions vary across the Arctic (Amstrup, Marcot \& Douglas, 2008). In several of the 19 polar bear subpopulations that are recognized by the IUCN/ SSC Polar Bear Specialist Group (Obbard et al., 2010) (Fig. 1), particularly those in the divergent and the seasonal ice ecoregions (sensu Amstrup et al., 2008) (Fig. 1), negative impacts of sea ice loss on body condition have been documented (Stirling, Lunn \& Iacozza, 1999; Obbard et al., 2006; Rode, Amstrup \& Regehr, 2010; Rode et al., 2012). This is expected to result in the decline of several polar bear subpopulations (Durner et al., 2009; Hunter et al., 2010; Molnár et al., 2010; Bromaghin et al., 2015), and also in multiple ecosystem-wide effects (Post et al., 2013).

Durner et al. (2009) projected that seasonally stable polar bear habitat will likely contract into one or few regions by the late 21st century: projections from nine out of ten evaluated global circulation models indicated an extensive decline of summer habitat, with the Canadian Arctic Archipelago and Greenland remaining as a refugium, and additional suitable habitat in the east Siberian, Laptev and/or Kara Sea. These regions would be isolated from each other each summer (Durner et al., 2009), fragmenting the polar bear distribution. Recent sea ice projections for the Canadian Arctic Archipelago have confirmed that its northern-most regions

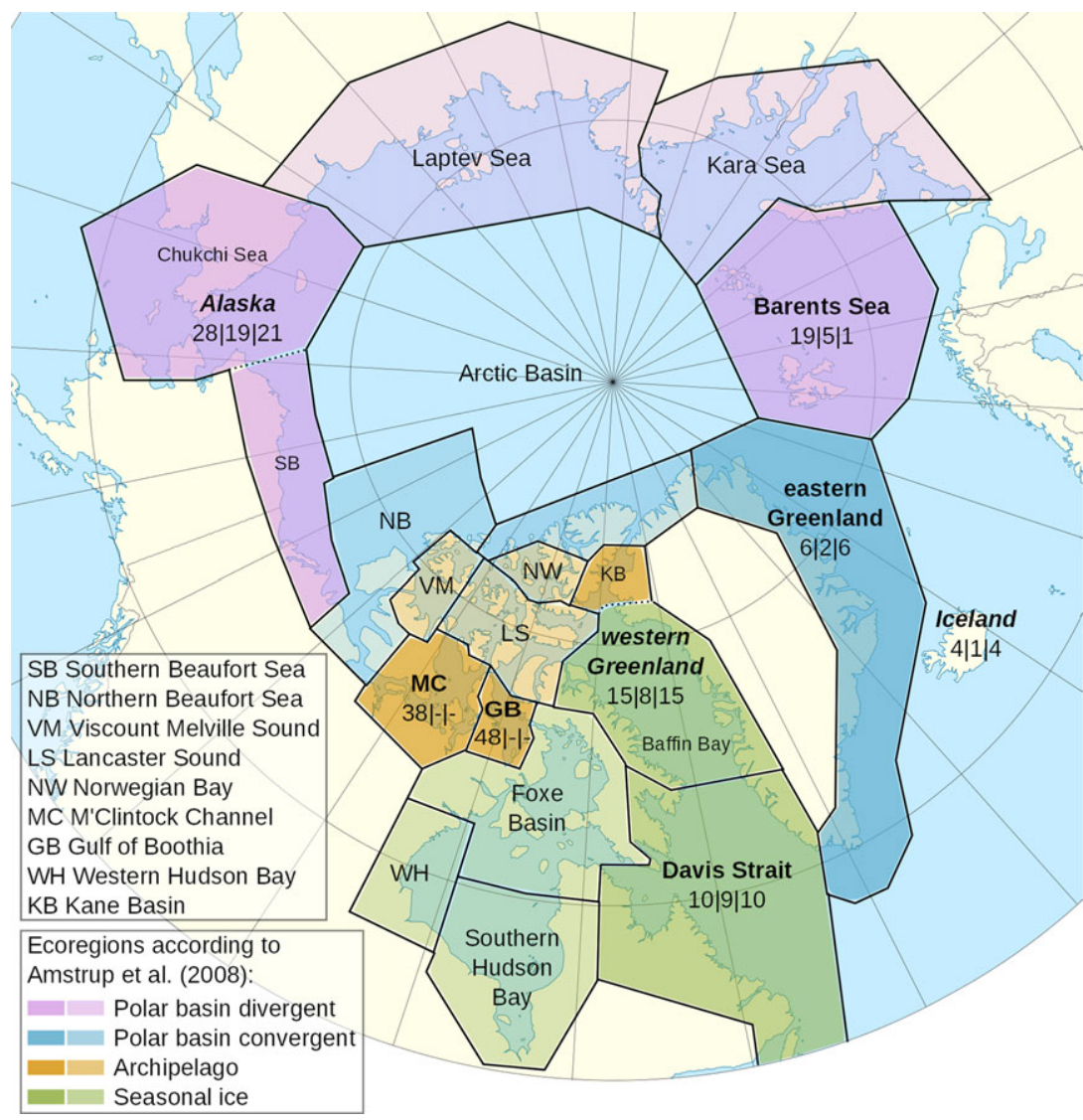

Figure 1 Map of all 19 polar bear subpopulations recognized by the IUCN/SSC Polar Bear Specialist Group (Obbard et al., 2010), showing the numbers of analyzed samples per subpopulation and marker system (mtDNA|Y chromosome|autosomal microsatellites). Dark and light colors: sampled and unsampled subpopulations/ ecoregions as defined by Amstrup et al. (2008), respectively. Subpopulation data from Chukchi Sea and Southern Beaufort Sea were combined and analyzed jointly (Alaska), as were data from Kane Basin and Baffin Bay (western Greenland), indicated by dotted lines. Modified from the Arctic Ocean location map by Tentotwo (Wikimedia Commons) under Creative Commons Attribution-Share Alike 3.0 Unported. 
will retain polar bear habitat the longest (Hamilton et al., 2014). Should suitable habitat eventually indeed contract into one single region, range-wide fragmentation would still occur on intermediate time scales (Durner et al., 2009; Peacock et al., 2015).

Loss of genetic variability in fragmented habitats can be counteracted by gene flow, mediated by long-distance movements of individuals beyond their natal areas (Keyghobadi, 2007). Besides the opportunity for passive drifting on sea ice (Amstrup \& Gardner, 1994; Mauritzen et al., 2003), polar bears have the capacity for active dispersal across large distances (Ferguson et al., 1999; Laidre et al., 2013). Extreme examples of individual movements are one satellite-tracked female covering almost $7200 \mathrm{~km}$ within 576 days, moving on sea ice from northern Alaska to northern Greenland (Durner \& Amstrup, 1995) and another female swimming 687 $\mathrm{km}$ within 9 days in the Beaufort Sea, followed by additional $1800 \mathrm{~km}$ swimming and walking over sea ice (Durner et al., 2011). Although long-distance swimming may come at energetic and reproductive costs (Durner et al., 2011), such long-distance vagrants or dispersers could have the potential to reach and reproduce in other subpopulations, helping to retain their demographic stability and genetic variability (Vilà et al., 2003).

Here we evaluate the genetic variability of vagrant polar bears that arrived on Iceland between 2008 and 2011. While Iceland is currently not part of the circumpolar distribution of polar bears (Obbard et al., 2010), more than 500 polar bears have been recorded reaching Iceland's shores since the 9th century, including about 50 individuals in the past 100 years (Haraldsson \& Hersteinsson, 2004). This recurrent influx of polar bears beyond their range may be a consequence of the high and rapid sea ice export out of the Arctic basin through Fram Strait, which plays an important role in regulating the amount of sea ice and freshwater in the Arctic Ocean and the Nordic Seas (Fahrbach et al., 2001). The passage is approximately $500 \mathrm{~km}$ wide, separating northeastern Greenland from the Svalbard archipelago in the east, and ice drift rates can be as high as $80 \mathrm{~km}$ per day (Perovich, Tucker \& Krishfield, 1989).

Although ecological conditions on Iceland preclude the establishment of a sustainable polar bear subpopulation (Amstrup, 2003), the individuals that reached Iceland illustrate the species' capacity for long-distance gene flow, even beyond current range boundaries. Hypothetically, vagrant individuals might only represent a small part of the species' gene pool, for example due to shared ancestry in a common source subpopulation. This would decrease the likelihood that a subpopulation would receive novel genetic variants from immigrants. However, consistent with the high dispersal capability of polar bears, genetic differentiation among the 19 recognized subpopulations is low (Paetkau et al., 1999; Edwards et al., 2011; Miller et al., 2012b; Campagna et al., 2013; Bidon et al., 2014; Cronin et al., 2014; Malenfant, Coltman \& Davis, 2015; Peacock et al., 2015). Further, a study that included data from 18 of the recognized subpopulations detected gene flow among clusters of subpopulations (Peacock et al., 2015). However, to our knowledge, no previous study has evaluated genetic aspects of long-distance dispersing or vagrant polar bears.

Here we compare the level of genetic variability found in four vagrant polar bears that arrived on Iceland to that in several polar bear subpopulations recognized by the IUCN/ SSC Polar Bear Specialist Group (Obbard et al., 2010) (Fig. 1). Our analyses are based on data from autosomal microsatellites, mitochondrial control region sequences, and Y-chromosomal sequence and microsatellite haplotypes, including previously published (Lindqvist et al., 2010; Hailer et al., 2012; Miller et al., 2012b; Campagna et al., 2013; Bidon et al., 2014) and newly generated data (the latter mainly to produce comparable microsatellite datasets, given known variation in allele sizes obtained from different instruments and size markers; e.g. Morin et al., 2009). Further, we use forward-time simulations to model genetic drift in a small polar bear population under complete isolation or with ongoing immigration to investigate the importance of connectivity among subpopulations.

\section{Materials and methods}

\section{Sampling and data}

We obtained 58 samples from across the polar bear range (Fig. 1), including 41 blood or tissue samples from Chukchi Sea and Southern Beaufort Sea (divergent ecoregion) and from Baffin Bay and Davis Strait (seasonal ice ecoregion), four tissue samples from vagrant individuals reaching Iceland, and 13 DNA samples from Barents Sea (divergent ecoregion), Kane Basin (Archipelago ecoregion), eastern Greenland (convergent ecoregion), Baffin Bay, Alaska (Chukchi Sea and Southern Beaufort Sea), and from a captive animal with unclear geographic ancestry. In addition, we used previously published data from 112 individuals (Lindqvist et al., 2010; Hailer et al., 2012; Miller et al., 2012b; Campagna et al., 2013; Bidon et al., 2014) from Alaska and the Barents Sea (divergent ecoregion), and from Gulf of Boothia and M'Clintock Channel (Archipelago ecoregion) (Fig. 1) that was collated from GenBank. The captive animal was excluded from some analyses. Detailed information on each individual is provided in Table S1. We note that our sampling for some subpopulations is relatively limited (Hale, Burg \& Steeves, 2012). We therefore merged the individuals from less well-sampled subpopulations with those of adjacent and not strongly differentiated subpopulations (based on Paetkau et al., 1999; Cronin, Amstrup \& Scribner, 2006; Peacock et al., 2015): Baffin Bay and Kane Basin were merged as 'western Greenland', Southern Beaufort Sea and Chukchi Sea as 'Alaska'.

\section{Mitochondrial DNA: PCR amplification, sequencing and analysis}

A hypervariable 681-bp fragment of the mitochondrial control region was already published for 51 of the 58 samples (Hailer et al., 2012; Bidon et al., 2014) (Table S1), the remaining seven individuals were sequenced (ENA accession 
Table 1 Mitochondrial genetic variability of polar bears from different subpopulations (Fig. 1)

\begin{tabular}{lrrrll}
\hline Subpopulation & $n$ & \multicolumn{1}{c}{$S$} & $N_{\mathrm{H}}$ & $H_{\mathrm{d}} \pm$ SD & $\pi \pm$ SD \\
\hline Vagrants $^{\mathrm{a}}$ & 4 & 8 & 4 & $1.00 \pm 0.18$ & $0.007 \pm 0.005$ \\
Barents Sea & 19 & 7 & 8 & $0.88 \pm 0.04$ & $0.003 \pm 0.002$ \\
Eastern Greenland & 6 & 6 & 4 & $0.80 \pm 0.17$ & $0.003 \pm 0.002$ \\
Western Greenland & 15 & 13 & 7 & $0.89 \pm 0.05$ & $0.006 \pm 0.004$ \\
Davis Strait & 10 & 5 & 4 & $0.53 \pm 0.18$ & $0.002 \pm 0.001$ \\
Alaska & 28 & 11 & 7 & $0.74 \pm 0.07$ & $0.005 \pm 0.003$ \\
Total/average & 82 & 19 & 20 & $0.88 \pm 0.02$ & $0.005 \pm 0.003$ \\
\hline
\end{tabular}

Analyses are based on sequences from a 681 bp long fragment from the mtDNA control region.

$n$ sample size (number of individuals); $S$, number of segregating sites; $N_{H}$ number of distinct haplotypes; $H_{d}$ haplotype diversity; $\pi$, nucleotide diversity.

${ }^{a}$ Vagrant polar bears reaching Iceland were analyzed as a group.

numbers: LN613410-LN613416) as described in Hailer et al. (2012). Primers and PCR conditions are listed in Table S2.

We added 26 previously published control region sequences $(681 \mathrm{bp})$ to a final alignment containing 84 individuals, including 19 sequences from the Barents Sea (Miller et al., 2012b) and seven from Alaska (Lindqvist et al., 2010; Miller et al., 2012b). For a second, shorter alignment, we collated 86 additional sequences with a length of $470 \mathrm{bp}$ from the M'Clintock Channel and Gulf of Boothia subpopulations (Campagna et al., 2013), yielding a total of 170 individuals (Fig. 1; Table S1).

We calculated estimates of within-population variability for five different subpopulations and for the vagrants (see Table 1) in Arlequin 3.5 (Excoffier \& Lischer, 2010). Phylogenetic relationships among inferred haplotypes were determined based on median-joining networks constructed using Network 4.612 (Bandelt, Forster \& Röhl, 1999) and based on phylogenetic trees using BEAST 1.7.4 (Drummond et al., 2012). A spatial analysis of variance was performed in SAMOVA v1.0 (Dupanloup, Schneider \& Excoffier, 2002) to identify groups of subpopulations $(K)$ that are geographically homogenous and genetically maximally differentiated from each other. Details on mtDNA analyses are provided in Appendix S1.

\section{Y chromosome markers: data compilation and analysis}

We used $3.1 \mathrm{~kb}$ of Y-specific sequence data and one Y-linked microsatellite marker (369.1) from 39 male polar bears (Bidon et al., 2014; Aarnes et al., 2015) to construct a statistical parsimony haplotype network in TCS 1.21 (Clement, Posada \& Crandall, 2000). These individuals had previously been sexed, using the approach of Bidon et al. (2013). This dataset includes the only male among the four vagrants that reached Iceland. In addition, sequences $(3.1 \mathrm{~kb})$ and microsatellite data for 369.1 were extracted from genomic sequence data of five males from Alaska and the Barents Sea (Miller et al., 2012b). Details and haplotype data are provided in Fig. 1 and the Appendices S1 and S2.
Table 2 Genetic variability of polar bears from different subpopulations (Fig. 1) at 23 autosomal microsatellites

\begin{tabular}{lclll}
\hline Subpopulation & \multicolumn{1}{c}{$n$} & $H_{\mathrm{E}} \pm \mathrm{SD}$ & $H_{\mathrm{O}} \pm \mathrm{SD}$ & $A_{\mathrm{R}}$ \\
\hline Vagrants $^{\mathrm{a}}$ & 4 & $0.72 \pm 0.05$ & $0.67 \pm 0.05$ & 3.5 \\
Eastern Greenland & 6 & $0.66 \pm 0.04$ & $0.64 \pm 0.04$ & 3.2 \\
Western Greenland & 15 & $0.70 \pm 0.03$ & $0.66 \pm 0.03$ & 3.3 \\
Davis Strait & 10 & $0.71 \pm 0.04$ & $0.66 \pm 0.03$ & 3.4 \\
Alaska $^{\text {Total/average }}{ }^{\mathrm{b}}$ & 21 & $0.68 \pm 0.03$ & $0.66 \pm 0.02$ & 3.3 \\
\hline
\end{tabular}

$n$, sample size (number of individuals); $H_{E}$ expected heterozygosity; $H_{O}$ observed heterozygosity; $A_{R}$ rarefied allelic richness (see Appendix S1).

${ }^{2}$ Vagrant polar bears reaching Iceland were analyzed as a group.

bIncludes two samples that were not counted in any of the shown subpopulation groupings (one from the Barents Sea and one captive).

\section{Autosomal microsatellites: PCR amplification, fragment and data analysis}

Each of the 58 samples was genotyped at 30 autosomal microsatellite loci in seven multiplex reactions as described in Appendix S1 and Table S2. Standard population genetic procedures were applied to test for Hardy-Weinberg equilibrium and linkage disequilibrium (Appendix S1) and to calculate diversity indices for four different subpopulations and the vagrants (see Table 2). A Principle Coordinate Analysis (PCoA) was calculated in GenAlEx 6.5 (Peakall \& Smouse, 2006, 2012) using all 58 individuals, based on a standardized pairwise genetic distance matrix. To determine population genetic structuring without pre-assigning individuals to sampling localities, we used the program STRUCTURE v2.3.1 (Pritchard, Stephens \& Donnelly, 2000). Details and genotype data are provided in Appendices S1 and S3.

Using R (R Core Team 2015), we randomly picked genotypes with replacement from our dataset to evaluate the variability of polar bears dispersing in other regions than Fram Strait, and evaluated their genetic variability as described above.

We performed forward-time simulations in EASYPOP 2.0.1 (Balloux, 2001) to evaluate the impact of continued immigration on the loss of genetic variability through genetic drift in two different demographic scenarios. Loss of genetic variability in an effective population of ten individuals was simulated (1) with no immigration and (2) receiving immigrants at a rate of one individual per generation from a large effective source population of 2000 individuals. Details are provided in Appendix S1.

\section{Results}

\section{Mitochondrial and Y-chromosomal markers}

In a 681-bp-fragment from the mitochondrial control region of 82 polar bears from the Barents Sea, Alaska, eastern Greenland, western Greenland, and the Davis Strait, i.e. from 
all four ecoregions according to Amstrup et al. (2008), and including four vagrant individuals that reached Iceland (Fig. 1), we found 19 segregating sites that defined 20 haplotypes. Haplotype diversity for the entire dataset was $0.88 \pm 0.02$ (mean $\pm \mathrm{SD}$ ) and nucleotide diversity was $0.005 \pm 0.003$ (Table 1). Overall, genetic structuring was weak among polar bear subpopulations. In a BEAST analysis, most branches had posterior support values below 0.95 (Fig. S1), except for one branch grouping haplotypes that were carried by individuals sampled in Alaska, western Greenland and Iceland. In a network of genetic variation, haplotypes from different subpopulations were closely related to each other (Fig. 2a). All four vagrant individuals carried different mitochondrial haplotypes that were not particularly closely related to each other. In our SAMOVA that excluded vagrant polar bears, $\mathrm{F}_{\mathrm{SC}}$ (genetic distance within groups) was minimized and significant for $K=4$ groups of subpopulations (Fig. S2). However, no corresponding $F_{\mathrm{CT}}$ value (genetic differentiation among groups) was significant, so $K=1$ could not be rejected. A similar lack of pronounced spatial population structuring was obtained from analyses of an extended mtDNA dataset from 170 polar bears, based on shorter (470-bp) control region sequences (Fig. S2 and S3; details in Appendix S1).
We identified seven haplotypes in a network of genetic variation at Y-linked sequence data and one Y-linked microsatellite (locus 369.1) from 44 male polar bears. These haplotypes were separated by seven mutational steps (Fig. 2b). The only single nucleotide polymorphism in the dataset was the same as already described in Bidon et al. (2014), separating five polar bears from Alaska and western Greenland from the remaining individuals. The five newly typed individuals [genome data from Miller et al. (2012b)] had three different Y-chromosomal haplotypes (Fig. 2b), each of them previously reported by Bidon et al. (2014). This included four samples from Svalbard (in the Barents Sea), a region yet uncharacterized for Y-linked markers, which carried two closely related haplotypes. The Y-chromosomal haplotype of the male polar bear that arrived on Iceland (all other samples of vagrants came from females) was also found in the Davis Strait and in western Greenland (Fig. 2b).

\section{Autosomal microsatellites}

We screened 30 autosomal microsatellite loci that had originally been developed for brown bears (Paetkau, Shields \& Strobeck, 1998; Kleven et al., 2012), American black bears
Figure 2 Haplotype networks of uniparentally inherited markers in polar bears from different subpopulations across their range. (a) Median joining network of genetic variation at a $681 \mathrm{bp}$ fragment of the mitochondrial control region in 83 polar bears. (b) Statistical parsimony network of $Y$ chromosome haplotypes, inferred from the unweighted combination of $3.1 \mathrm{~kb}$ sequence data and microsatellite locus 369.1. *Haplotype determined by a single nucleotide polymorphism.

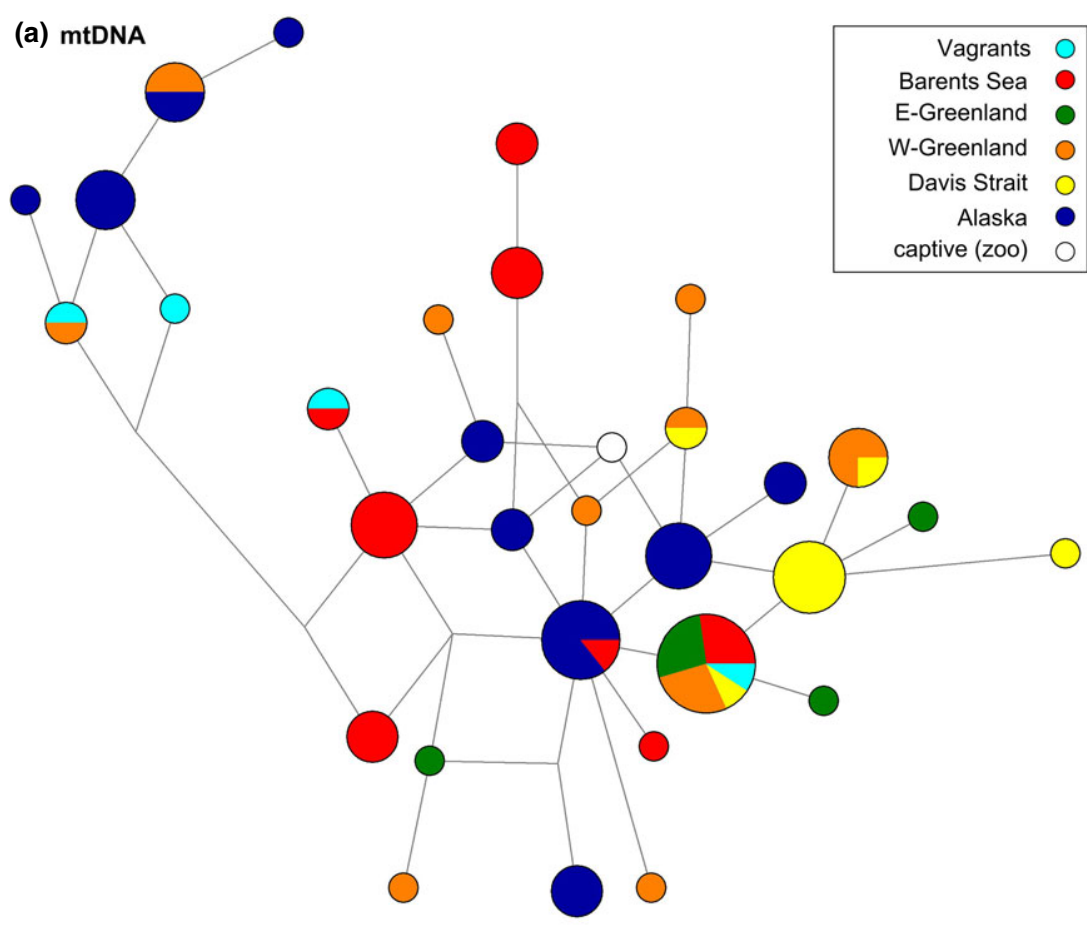

(b) Y chromosome

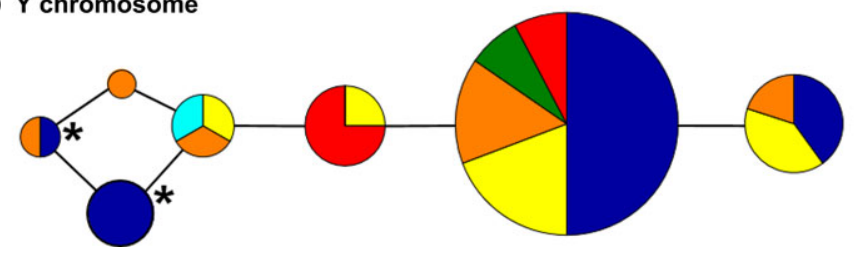


(Paetkau \& Strobeck, 1994), Asiatic black bears (Kitahara et al., 2000) or polar bears (Paetkau et al., 1995) for utility and variability in 58 polar bear samples covering subpopulations from all four ecoregions (Amstrup et al., 2008). Seven loci failed in PCR or were monomorphic in polar bears, leaving 23 microsatellite loci (Tables S2 and S3) for all following analyses. This included thirteen brown bear loci from Kleven et al. (2012), which here are shown to be highly polymorphic in polar bears (Appendix S1). No linkage disequilibrium was found for any pair of loci in any subpopulation $(P>0.05$ after sequential Bonferroni correction). We found significant departure from Hardy-Weinberg equilibrium in one instance in one subpopulation (locus UarD1585 in western Greenland; $P<0.001$ ).

In the analyzed subpopulations, expected heterozygosity $\left(H_{\mathrm{E}}\right)$ across autosomal loci ranged from $0.66 \pm 0.04$ (mean $\pm \mathrm{SD}$ ) in eastern Greenland to $0.71 \pm 0.04$ in the Davis Strait, and allelic richness $\left(A_{\mathrm{R}}\right)$ ranged from 3.2 in eastern Greenland to 3.4 in the Davis Strait (Table 2). The four vagrants that reached Iceland tended to show slightly higher variability when analyzed as a group $\left(H_{\mathrm{E}}=0.72 \pm\right.$ 0.05, $A_{\mathrm{R}}=3.5$ ). For comparison, four randomly picked genotypes from the most extensively sampled subpopulation (Alaska) yielded lower variability across 100 replicates (average $H_{\mathrm{E}}=0.67 \pm 0.04, A_{\mathrm{R}}=3.2$ ) than the vagrants, but with overlapping standard deviations. Similar estimates were obtained when randomly re-sampling four genotypes 100 times from across the entire range (average $H_{\mathrm{E}}=0.70 \pm 0.03$, $A_{\mathrm{R}}=3.3$ ). Both estimates from randomly picked individuals overlapped with estimates from recognized subpopulations, indicating the vagrants exhibited marginally but nonsignificantly higher variability than other individuals. The proportion of heterozygous loci per individual (individual heterozygosity) ranged from $30 \%$ to $87 \%$ in individuals from established subpopulations and from $57 \%$ to $87 \%$ in the vagrants.

A PCoA (Fig. 3a) revealed weak geographic structuring. All vagrants clustered at different positions in the plot. One vagrant was somewhat disjunct from other polar bears (but overall not strongly divergent), the other three vagrants clustered closely to individuals from Alaska or from eastern and western Greenland. Pairwise $\Theta_{\mathrm{ST}}$ values between subpopulations were low and ranged from 0.012 (Davis Strait/western Greenland) to 0.044 (Alaska/Davis Strait) (Table S4). Despite low differentiation levels among subpopulations, most $\Theta_{\text {ST }}$ values were significant, except for the differentiation of Davis Strait and western Greenland. All pairwise comparisons including vagrants yielded low and non-significant $\Theta_{\mathrm{ST}}$ values.

Admixture analyses using STRUCTURE confirmed weak population structuring. When not using the geographic sample origin as prior information, all individuals showed admixture for $K=2-10$ clusters, proportional to the numbers of assumed clusters (Fig. 3b). A more pronounced signal of genetic structuring was obtained when including the geographic origin of each sample as prior information [locprior model (Hubisz et al., 2009)] (Fig. 3c), but parameters $\alpha$ and $r$ did not converge within 3 million iterations, despite multi- ple runs with different settings. Using the locprior model, $\Delta K$ was highest for $K=3$, with Alaskan polar bears assigned to one cluster, individuals from the Davis Strait and western Greenland assigned to a second cluster and four eastern Greenlandic polar bears assigned to a third cluster. All vagrant individuals showed admixture, but each with a different clustering composition (Fig. 3c).

We performed forward-time simulations of genetic drift based on small populations with similar levels of genetic variability as encompassed by the polar bears that reached Iceland. Ten reproducing individuals were simulated assuming a ratio of effective to actual population size of 0.1 (Frankham, 1995; but see Palstra \& Ruzzante, 2008), and an actual population size of 100 based on the size of the three smallest recognized subpopulations that include 94-278 polar bears (Obbard et al., 2010). In a scenario of complete isolation, $36 \%( \pm 3 \%)$ (mean $\pm \mathrm{SD}$ ) or $90 \%( \pm 4 \%)$ of the genetic variability had been lost after 10 or 50 generations, respectively (Fig. 4). In contrast, when simulated populations were connected by migration at a rate of one individual per generation (roughly mirroring the historical records for Iceland), levels of expected heterozygosity remained relatively constant over time and only $15 \%( \pm 4 \%)$ of the genetic variability had been lost after 50 generations.

\section{Discussion}

\section{Comparably high genetic variability of vagrant polar bears on Iceland}

Genetic characteristics of the four vagrant polar bears that reached Iceland show that relatively few individuals arriving at a given location can represent a substantial proportion of the species' gene pool. Individual heterozygosity of each of the four vagrants falls within the range observed among individuals sampled in recognized subpopulations. As a group, the vagrants encompass a slightly but non-significantly higher level of genetic variability than what is present in recognized subpopulations - despite the limited number of vagrants included in our study.

The high variability encompassed by the four vagrants might be the result of the particular sea ice conditions in Fram Strait. A likely route for polar bears arriving on Iceland is from the east coast of Greenland on pack ice that is exported out of Fram Strait, which is the primary region of sea ice export from the Arctic basin (Perovich et al., 1989). The eastern Greenland subpopulation is geographically closest to Iceland and polar bears roam along the entire coastline (Laidre et al., 2015a), so eastern Greenland has been assumed to be the source of polar bears reaching Iceland (Vetter, Gall \& Skírnisson, 2015). However, our study suggests that besides the geographically proximate subpopulation of eastern Greenland, vagrants arriving on Iceland may come from subpopulations from all four ecoregions (Amstrup et al., 2008): the vagrant individuals are most genetically similar to individuals from eastern Greenland, western Greenland, and Alaska, and each shows different clustering affinities for autosomal microsatellites. Further, the four 
Figure 3 Genetic structuring of polar bears from different subpopulations across their range at autosomal microsatellite markers. (a) Principal Coordinate Analysis of 58 polar bears, genotyped at 23 autosomal microsatellite loci. (b) Admixture analyses in STRUCTURE of 58 individual autosomal genotypes without using any prior population information; (c) same as (b), but using the locprior model. Each color represents one cluster and each bar represents one individual.

(a)

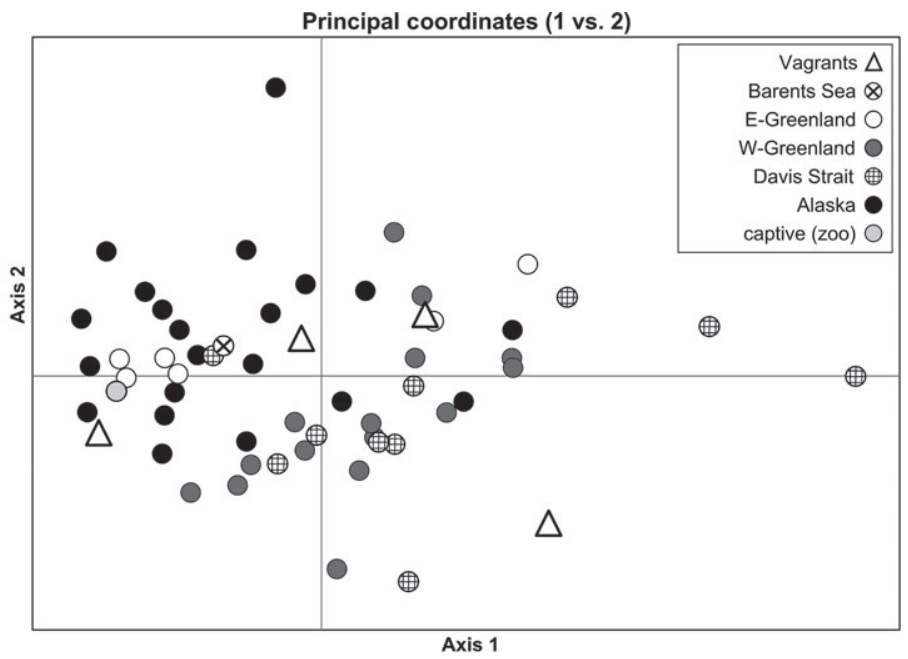

(b) No population information $K=2$

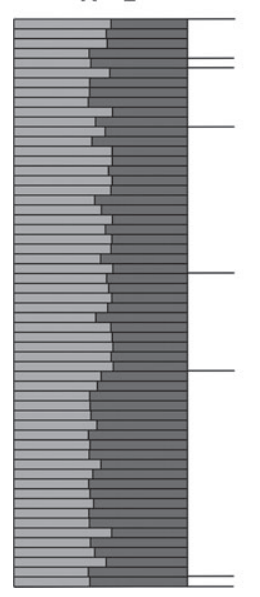

(c)

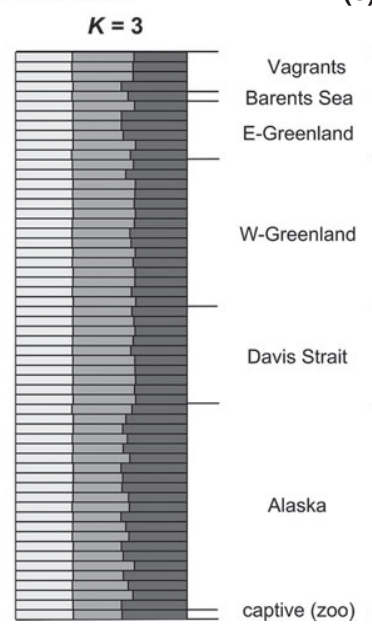

Locprior model

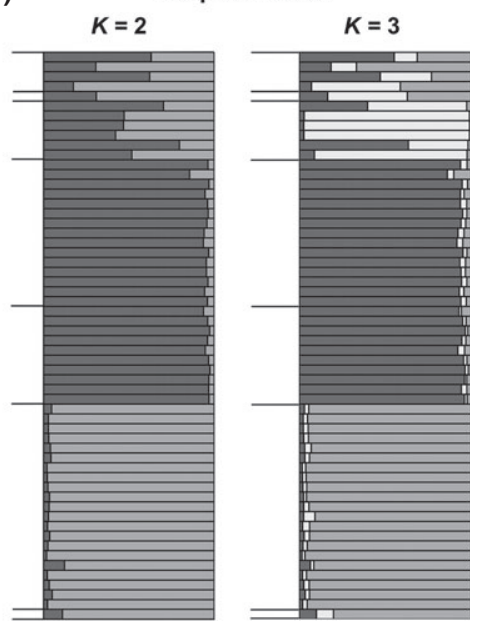

individuals carry four different mitochondrial haplotypes, of which two belong to a statistically highly supported lineage otherwise found in Alaska, western Greenland and Canadian subpopulations (M'Clintock Channel and Gulf of Boothia). This signal from differentially inherited genetic markers suggests that the polar bears reaching Iceland may have had different geographic origins. However, the weak range-wide geographic structuring in polar bears precludes a definite assignment to a particular source region.

We propose two complementary explanations why already a low number of polar bears can capture a large proportion of the species' gene pool. Notably, this reasoning is not restricted to Fram Strait, but is likely applicable to anywhere in the range.

First, polar bears show low overall genetic variability. Nucleotide diversity of polar bears is only circa $20-25 \%$ of that found in brown bears (Hailer et al., 2012; Miller et al., 2012b; Liu et al., 2014). This large difference between the two species reflects severe population bottlenecks in polar bears (Miller et al., 2012b; Liu et al., 2014), but likely also their smaller distribution range and population size compared to brown bears (McLellan, Servheen \& Huber, 2008; Wiig et al., 2015).

Second, the largest proportion of genetic variance in polar bears is not found among subpopulations, but instead among individuals - regardless of their subpopulation origin. The high dispersal capability of polar bears (Ferguson et al., 1999; Laidre et al., 2013) enables them to cover considerable distances (Durner \& Amstrup, 1995; Durner et al., 2011). This has resulted in only weak range-wide population genetic structuring that is visible in our data from autosomal microsatellites, the Y chromosome and mtDNA. Similar low levels of population differentiation have been previously reported for mtDNA (Edwards et al., 2011; Campagna et al., 2013; Peacock et al., 2015), autosomal microsatellites (Paetkau et al., 1999; Peacock et al., 2015), Y-chromosomal data (Bidon et al., 2014), autosomal introns (Hailer et al., 2012), and genome-wide data (Miller et al., 2012b; Cahill et al., 2013; Cronin et al., 2014; Malenfant et al., 2015).

Comparing estimates of population differentiation among polar bear subpopulations obtained from maternally inherited mtDNA and paternally inherited Y-chromosomal markers, 


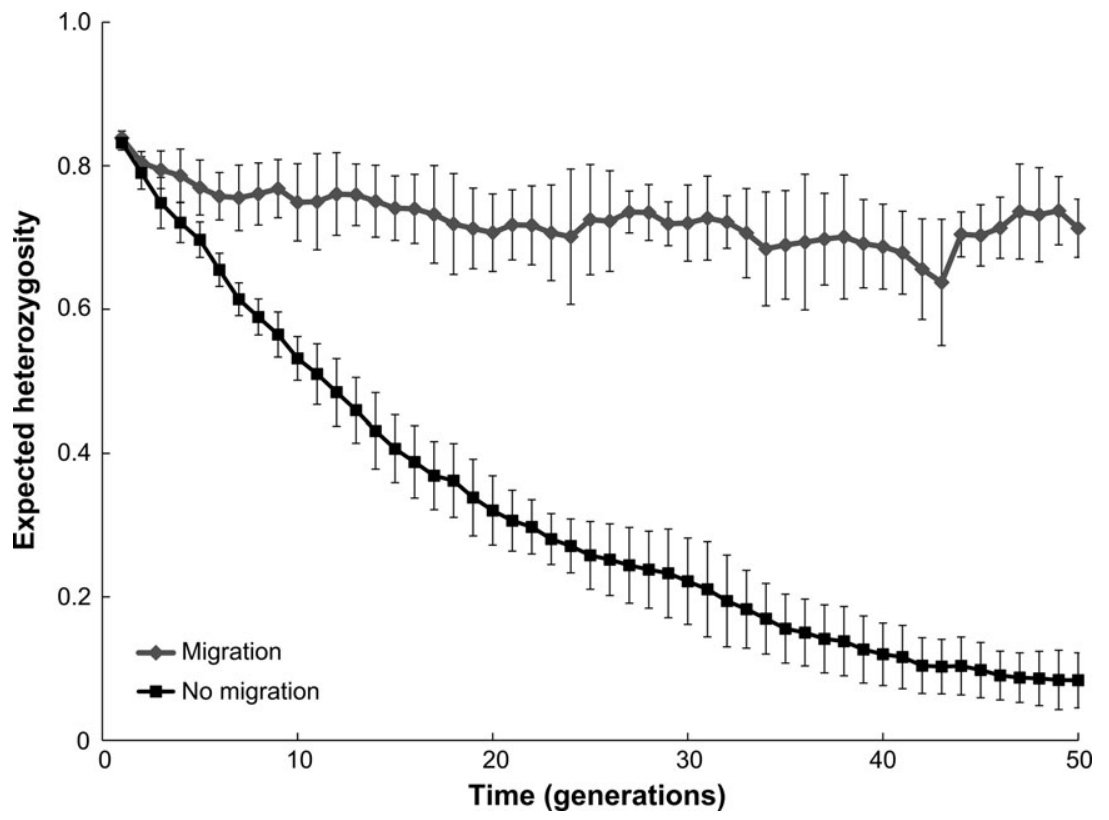

Figure 4 Simulated loss of genetic variability in a population of ten individuals. Two simulation scenarios were investigated: (1) migration at a rate of one individual per generation and (2) no migration. Lines are averages $( \pm \mathrm{SD})$ across 10 simulations. respectively, Bidon et al. (2014) did not observe pronounced differences between the two marker systems, implying less strongly sex-biased dispersal in polar than in brown bears (Bidon et al., 2014). This is consistent with our results and with analyses of movement data that found males to travel similar (Laidre et al., 2013) or only slightly larger (Amstrup et al., 2001) mean distances than females.

\section{Importance of long-distance dispersal for future genetic variability of polar bears}

Some late Pleistocene polar bear populations appear to have become isolated in coastal regions south of the current range, near the Alaskan Admiralty, Baranof and Chichagof islands (Cahill et al., 2013), Ireland (Edwards et al., 2011) and Pleistocene Beringia (Barnes et al., 2002). At these locations, polar bears hybridized with brown bears, leaving a genetic footprint in resident brown bear populations (Cahill et al., 2013). These observations show that climate-related changes in Arctic habitats can isolate polar bear populations from their conspecifics.

Large-scale reductions in summer sea ice extent have been projected, fragmenting the remaining habitat into one or several regions by the late 21st century (Amstrup et al., 2008; Durner et al., 2009; Hamilton et al., 2014). Until that time, polar bears will face intermediate levels of habitat fragmentation (Durner et al., 2009; Peacock et al., 2015), likely with regional differences: Amstrup et al. (2008) projected the convergent and Archipelago ecoregions to maintain polar bear habitat the longest, similar to projections by Durner et al. (2009), that, however, suggest local deviations from this large-scale pattern.

Late winter and early spring sea ice is currently permitting large-scale movements across subpopulation boundaries during the mating season (March-May) (Amstrup, 2003; Laidre et al., 2013). However, already under current sea ice conditions, genetic differentiation among subpopulations is discernible (Paetkau et al., 1999; Campagna et al., 2013; Malenfant et al., 2015; Peacock et al., 2015). With projections of increasing duration of the ice-free season in summer (IPCC, 2014), the period available for dispersal across sea ice is expected to shorten over the next decades (Durner et al., 2009; Peacock et al., 2015). While these habitat changes are likely to lead to a merging of some of the currently recognized subpopulations (Paetkau et al., 1999; Cronin et al., 2006; Peacock et al., 2015), other subpopulations are likely to become isolated from each other each summer (Obbard et al., 2010).

As predicted by population genetic theory (Nei, Maruyama \& Chakraborty, 1975), our genetic drift simulations revealed that genetic variability would decline severely within only few generations in a completely isolated population. In contrast, continued immigration decelerated the decline in genetic variability in our simulations. Indeed, genetic diversity decreased significantly in an isolated Italian brown bear $U$. arctos population within less than one generation (De Barba et al., 2010), and gene flow into isolated wolf and bighorn sheep Ovis canadensis populations has been shown to assist in the preservation of genetic diversity (Vilà et al., 2003; Miller et al., 2012a). The comparably high genetic diversity observed in vagrant polar bears reaching Iceland and in randomly picked individuals implies that vagrant or dispersing polar bears can potentially carry novel genetic variants into other subpopulations. Hence, in the projected fragmented Arctic habitats of the 21 st century, dispersing polar bears will likely become increasingly important for subpopulation connectivity, buffering against subpopulation size fluctuations and declines of genetic diversity. 


\section{Long-distance dispersal in the Arctic and its conservation implications}

Even under scenarios where polar bears eventually may be restricted to one remaining refugium (Amstrup et al., 2008; Durner et al., 2009; Hamilton et al., 2014), preservation of genetic diversity will be an important long-term management goal to safeguard evolutionary potential (Reed \& Frankham, 2003). Hence, albeit not surprising from a theoretical standpoint, our results highlight an aspect that has not received much attention in polar bear management (Obbard et al., 2010), possibly because it is difficult to influence (Crooks \& Sanjayan, 2006): that factors contributing to maintained connectivity in fragmented habitats should receive conservation attention (Heller \& Zavaleta, 2009).

Management decisions in the face of increased population fragmentation due to further sea ice loss are complex and will likely involve a mix of strategies ranging from the individual to the habitat level (Hodgson et al., 2009) [see e.g. Sahanatien \& Derocher (2012); Vongraven et al. (2012); Derocher et al. (2013) for a detailed discussion of effective polar bear management and conservation]. A reduction of greenhouse gas emissions on a global scale is expected to positively affect the amount and quality of sea ice habitat (e.g. Amstrup et al., 2010; Laidre et al., 2015b). Translocations of polar bears are difficult and considered an unviable option under most circumstances (Derocher et al., 2013). Nevertheless, monitoring schemes of mortality, movement patterns, subpopulation status, physiology and sea ice concentration will yield important data for future management decisions (Sahanatien \& Derocher, 2012; Vongraven et al., 2012; Derocher et al., 2013). This could include more targeted tagging studies in key areas, and intensified international cooperation to share and analyze movement data. One possible outcome of monitoring could be the identification of regions that are particularly important for subpopulation connectivity (Heller \& Zavaleta, 2009). Further, continued genetic sampling will allow monitoring subpopulation differentiation and variability over time (Vongraven et al., 2012).

Given recent climate projections (IPCC, 2014), population connectivity is likely to be reduced not only for polar bears, but for other Arctic species as well. Similar to polar bears, Arctic foxes currently show extensive levels of gene flow across most of their range with sea ice occurrence explaining regional variation in connectivity (Geffen et al., 2007). Interestingly, Arctic foxes follow polar bears in their movements, scavenging on remains from their kills (Chesemore, 1968), so the population genetic structuring of these two carnivores is interrelated in multiple ways (Paetkau et al., 1999; Dalén et al., 2005; Norén et al., 2011; Peacock et al., 2015). Other terrestrial taxa utilize Arctic sea ice for dispersal as well, such as Canadian gray wolves (Carmichael et al., 2008). Sea ice loss could therefore decrease connectivity and perhaps also genetic diversity in several species of conservation concern, with associated risk of reduced fitness and loss of evolutionary potential (Reed \& Frankham, 2003).

\section{Acknowledgements}

This work was supported by LOEWE Landes-Offensive zur Entwicklung Wissenschaftlich-ökonomischer Exzellenz, the Arthur und Aenne Feindt-Stiftung, Hamburg, and the Department of Environment, Government of Nunavut. The findings and conclusions in this article are those of the author(s) and do not necessarily represent the views of the U.S. Fish and Wildlife Service. We thank Urmas Saarma for providing us with samples, Johan Liakka and Thomas Müller for discussions, and anonymous reviewers and the editors for helpful comments.

\section{References}

Aarnes, S.G., Hagen, S.B., Andreassen, R., Schregel, J., Knappskog, P.M., Hailer, F., Stenhouse, G., Janke, A. \& Eiken, H.G. (2015). Y-chromosomal testing of brown bears (Ursus arctos): Validation of a multiplex PCR-approach for nine STRs suitable for fecal and hair samples. Forensic Sci. Int. Genetics 19, 197-204.

Amstrup, S.C. (2003). The Polar Bear - Ursus maritimus. In Wild mammals of North America: biology, management, and conservation: 587-610. Feldhamer, G.A., Thompson, B.C. \& Chapman, J.A. (Eds). Baltimore: The John Hopkins University Press.

Amstrup, S.C. \& Gardner, C. (1994). Polar Bear Maternity Denning in the Beaufort Sea. J. Wildl. Manage. 58, 1-10.

Amstrup, S.C., Durner, G.M., McDonald, T.L., Mulcahy, D.M. \& Garner, G.W. (2001). Comparing movement patterns of satellite-tagged male and female polar bears. Can. J. Zool. 79, 2147-2158.

Amstrup, S.C., Marcot, B.G. \& Douglas, D.C. (2008). A Bayesian network modeling approach to forecasting the 21st century worldwide status of polar bears. In Geophysical monograph series: 213-268. DeWeaver, E.T., Bitz, C.M. \& Tremblay, L.-B. (Eds). Washington: American Geophysical Union.

Amstrup, S.C., DeWeaver, E.T., Douglas, D.C., Marcot, B.G., Durner, G.M., Bitz, C.M. \& Bailey, D.A. (2010). Greenhouse gas mitigation can reduce sea-ice loss and increase polar bear persistence. Nature 468, 955958.

Balloux, F. (2001). EASYPOP (Version 1.7): A Computer Program for Population Genetics Simulations. J. Hered. 92, 301-302.

Bandelt, H.J., Forster, P. \& Röhl, A. (1999). Median-joining networks for inferring intraspecific phylogenies. Mol. Biol. Evol. 16, 37-48.

Barnes, I., Matheus, P., Shapiro, B., Jensen, D. \& Cooper, A. (2002). Dynamics of Pleistocene Population Extinctions in Beringian Brown Bears. Science 295, 2267-2270.

Baum, K.A., Haynes, K.J., Dillemuth, F.P. \& Cronin, J.T. (2004). The matrix enhances the effectiveness of corridors and stepping stones. Ecology 85, 2671-2676. 
Bidon, T., Frosch, C., Eiken, H.G., Kutschera, V.E., Hagen, S.B., Aarnes, S.G., Fain, S.R., Janke, A. \& Hailer, F. (2013). A sensitive and specific multiplex PCR approach for sex identification of ursine and tremarctine bears suitable for noninvasive samples. Mol. Ecol. Resour. 13, 362-368.

Bidon, T., Janke, A., Fain, S.R., Eiken, H.G., Hagen, S.B., Saarma, U., Hallström, B.M., Lecomte, N. \& Hailer, F. (2014). Brown and Polar Bear Y Chromosomes Reveal Extensive Male-Biased Gene Flow within Brother Lineages. Mol. Biol. Evol. 31, 1353-1363.

Bromaghin, J.F., McDonald, T.L., Stirling, I., Derocher, A.E., Richardson, E.S., Regehr, E.V., Douglas, D.C., Durner, G.M., Atwood, T. \& Amstrup, S.C. (2015). Polar bear population dynamics in the southern Beaufort Sea during a period of sea ice decline. Ecol. Appl. 25, 634-651.

Cahill, J.A., Green, R.E., Fulton, T.L., Stiller, M., Jay, F., Ovsyanikov, N., Salamzade, R., St. John, J., Stirling, I., Slatkin, M. and Shapiro, B. (2013). Genomic Evidence for Island Population Conversion Resolves Conflicting Theories of Polar Bear Evolution. PLoS Genet.. 9, e1003345.

Campagna, L., Coeverden, Van, de Groot, P.J., Saunders, B.L., Atkinson, S.N., Weber, D.S., Dyck, M.G., Boag, P.T. \& Lougheed, S.C. (2013). Extensive sampling of polar bears (Ursus maritimus) in the Northwest Passage (Canadian Arctic Archipelago) reveals population differentiation across multiple spatial and temporal scales. Ecol. Evol. 3, 3152-3165.

Carmichael, L.E., Krizan, J., Nagy, J.A., Dumond, M., Johnson, D., Veitch, A. \& Strobeck, C. (2008). Northwest passages: conservation genetics of Arctic Island wolves. Conserv. Genet. 9, 879-892.

Chesemore, D.L. (1968). Notes on the food habits of Arctic foxes in northern Alaska. Can. J. Zool. 46, 1127-1130.

Clement, M., Posada, D. \& Crandall, K.A. (2000). TCS: a computer program to estimate gene genealogies. Mol. Ecol. 9, 1657-1659.

Cronin, M.A., Amstrup, S.C. \& Scribner, K.T. (2006). Microsatellite DNA and mitochondrial DNA variation in polar bears (Ursus maritimus) from the Beaufort and Chukchi seas, Alaska. Can. J. Zoolog. 84, 655-660.

Cronin, M.A., Rincon, G., Meredith, R.W., MacNeil, M.D., Islas-Trejo, A., Cánovas, A. \& Medrano, J.F. (2014). Molecular Phylogeny and SNP Variation of Polar Bears (Ursus maritimus), Brown Bears (U. arctos), and Black Bears (U. americanus) Derived from Genome Sequences. $J$. Hered. 105, 312-323.

Crooks, K.R. \& Sanjayan, M. (2006). Connectivity conservation. Cambridge: Cambridge University Press.

Dalén, L., Fuglei, E., Hersteinsson, P., Kapel, C.M.O., Roth, J.D., Samelius, G., Tannerfeldt, M. \& Angerbjörn, A. (2005). Population history and genetic structure of a circumpolar species: the arctic fox. Biol. J. Linn. Soc. 84, 79-89.

De Barba, M., Waits, L.P., Garton, E.O., Genovesi, P., Randi, E., Mustoni, A. \& Groff, C. (2010). The power of genetic monitoring for studying demography, ecology and genetics of a reintroduced brown bear population. Mol. Ecol. 19, 3938-3951.

Derocher, A.E., Aars, J., Amstrup, S.C., Cutting, A., Lunn, N.J., Molnár, P.K., Obbard, M.E., Stirling, I., Thiemann, G.W., Vongraven, D., Wiig, Ø. \& York, G. (2013). Rapid ecosystem change and polar bear conservation. Conserv. Lett. 6, 368-375.

Drummond, A.J., Suchard, M.A., Xie, D. \& Rambaut, A. (2012). Bayesian phylogenetics with BEAUti and the BEAST 1.7. Mol. Biol. Evol. 29, 1969-1973.

Dupanloup, I., Schneider, S. \& Excoffier, L. (2002). A simulated annealing approach to define the genetic structure of populations. Mol. Ecol. 11, 2571-2581.

Durner, G.M. \& Amstrup, S.C. (1995). Movements of a Polar Bear from Northern Alaska to Northern Greenland. Arctic 48, 338-341.

Durner, G.M., Douglas, D.C., Nielson, R.M., Amstrup, S.C., McDonald, T.L., Stirling, I., Mauritzen, M., Born, E.W., Wiig, Ø., DeWeaver, E., Serreze, M.C., Belikov, S.E., Holland, M.M., Maslanik, J., Aars, J., Bailey, D.A. \& Derocher, A.E. (2009). Predicting 21st-century polar bear habitat distribution from global climate models. Ecol. Monograph. 79, 25-58.

Durner, G.M., Whiteman, J.P., Harlow, H.J., Amstrup, S.C., Regehr, E.V. \& Ben-David, M. (2011). Consequences of long-distance swimming and travel over deep-water pack ice for a female polar bear during a year of extreme sea ice retreat. Polar Biol. 34, 975-984.

Edwards, C.J., Suchard, M.A., Lemey, P., Welch, J.J., Barnes, I., Fulton, T.L., Barnett, R., O'Connell, T.C., Coxon, P., Monaghan, N., Valdiosera, C.E., Lorenzen, E.D., Willerslev, E., Baryshnikov, G.F., Rambaut, A., Thomas, M.G., Bradley, D.G. \& Shapiro, B. (2011). Ancient Hybridization and an Irish Origin for the Modern Polar Bear Matriline. Curr. Biol. 21, 1251-1258.

Excoffier, L. \& Lischer, H.E.L. (2010). Arlequin suite ver 3.5: a new series of programs to perform population genetics analyses under Linux and Windows. Mol. Ecol. Resour. 10, 564-567.

Fahrbach, E., Meincke, J., Østerhus, S., Rohardt, G., Schauer, U., Tverberg, V. \& Verduin, J. (2001). Direct measurements of volume transports through Fram Strait. Polar Res. 20, 217-224.

Ferguson, S., Taylor, M., Born, E., Rosing-Asvid, A. \& Messier, F. (1999). Determinants of Home Range Size for Polar Bears (Ursus maritimus). Ecol. Lett. 2, 311-318.

Fischer, J. \& Lindenmayer, D.B. (2007). Landscape modification and habitat fragmentation: a synthesis. Global Ecol. Biogeogr. 16, 265-280.

Frankham, R. (1995). Effective population size/adult population size ratios in wildlife: a review. Genet. Res. 66, 95-107.

Gascon, C., Lovejoy, T.E., Bierregaard, R.O. Jr, Malcolm, J.R., Stouffer, P.C., Vasconcelos, H.L., Laurance, W.F., 
Zimmerman, B., Tocher, M. \& Borges, S. (1999). Matrix habitat and species richness in tropical forest remnants. Biol. Conserv. 91, 223-229.

Geffen, E., Waidyaratne, S., Dalén, L., Angerbjörn, A., Vila, C., Hersteinsson, P., Fuglei, E., White, P.A., Goltsman, M., Kapel, C.M.O. \& Wayne, R.K. (2007). Sea ice occurrence predicts genetic isolation in the Arctic fox. Mol. Ecol. 16, 4241-4255.

Hailer, F., Kutschera, V.E., Hallström, B.M., Klassert, D., Fain, S.R., Leonard, J.A., Arnason, U. \& Janke, A. (2012). Nuclear Genomic Sequences Reveal that Polar Bears Are an Old and Distinct Bear Lineage. Science 336, 344-347.

Hale, M.L., Burg, T.M. \& Steeves, T.E. (2012). Sampling for Microsatellite-Based Population Genetic Studies: 25 to 30 Individuals per Population Is Enough to Accurately Estimate Allele Frequencies. PLOS ONE 7, e45170.

Hamilton, S.G., Castro de la Guardia, L., Derocher, A.E., Sahanatien, V., Tremblay, B. \& Huard, D. (2014). Projected Polar Bear Sea Ice Habitat in the Canadian Arctic Archipelago. PLOS ONE 9, e113746.

Hamrick, J.L. \& Godt, M.J.W. (1996). Effects of Life History Traits on Genetic Diversity in Plant Species. Philos. T. Roy. Soc. B. 351, 1291-1298.

Hanski, I. \& Gaggiotti, O.E. (2004). Ecology, genetics, and evolution of metapopulations. San Diego: Elsevier Academic Press.

Haraldsson, T. \& Hersteinsson, P. (2004). Hvítabjörn (Polar bear). In Íslensk spendýr (Icelandic mammals): 102-107. Hersteinsson, P. (Ed). Vaka-Helgafell: Reykjavík.

Heller, N.E. \& Zavaleta, E.S. (2009). Biodiversity management in the face of climate change: A review of 22 years of recommendations. Biol. Conserv. 142, 14-32.

Hodgson, J.A., Thomas, C.D., Wintle, B.A. \& Moilanen, A. (2009). Climate change, connectivity and conservation decision making: back to basics. J. Appl. Ecol. 46, 964969.

Hubisz, M.J., Falush, D., Stephens, M. \& Pritchard, J.K. (2009). Inferring weak population structure with the assistance of sample group information. Mol. Ecol. Resour. 9, 1322-1332.

Hunter, C.M., Caswell, H., Runge, M.C., Regehr, E.V., Amstrup, S.C. \& Stirling, I. (2010). Climate change threatens polar bear populations: a stochastic demographic analysis. Ecology 91, 2883-2897.

IPCC (2014). Climate change 2014: impacts, adaptation, and vulnerability. Part B: regional aspects. Contribution of working group II to the fifth assessment report of the intergovernmental panel on climate change. Cambridge and New York: Cambridge University Press.

Kelly, B.P., Badajos, O.H., Kunnasranta, M., Moran, J.R., Martinez-Bakker, M., Wartzok, D. \& Boveng, P. (2010). Seasonal home ranges and fidelity to breeding sites among ringed seals. Polar Biol. 33, 1095-1109.

Keyghobadi, N. (2007). The genetic implications of habitat fragmentation for animals. Can. J. Zool. 85, 1049-1064.
Kitahara, E., Isagi, Y., Ishibashi, Y. \& Saitoh, T. (2000). Polymorphic microsatellite DNA markers in the Asiatic black bear Ursus thibetanus. Mol. Ecol. 9, 1661-1662.

Kleven, O., Hallström, B., Hailer, F., Janke, A., Hagen, S., Kopatz, A. \& Eiken, H.G. (2012). Identification and evaluation of novel di- and tetranucleotide microsatellite markers from the brown bear (Ursus arctos). Conserv. Genet. Resour. 4, 737-741.

Laidre, K.L., Born, E.W., Gurarie, E., Wiig, Ø., Dietz, R. \& Stern, H. (2013). Females roam while males patrol: divergence in breeding season movements of pack-ice polar bears (Ursus maritimus). P. Roy. Soc. B-Biol. Sci. 280, 20122371.

Laidre, K.L., Born, E.W., Heagerty, P., Wiig, Ø., Stern, H., Dietz, R., Aars, J. and Andersen, M. (2015a). Shifts in female polar bear (Ursus maritimus) habitat use in East Greenland. Polar Biol. 1-15.

Laidre, K.L., Stern, H., Kovacs, K.M., Lowry, L., Moore, S.E., Regehr, E.V., Ferguson, S.H., Wiig, Ø., Boveng, P., Angliss, R.P., Born, E.W., Litovka, D., Quakenbush, L., Lydersen, C., Vongraven, D. \& Ugarte, F. (2015b). Arctic marine mammal population status, sea ice habitat loss, and conservation recommendations for the 21 st century.

Conserv. Biol. 29, 724-737.

Lindqvist, C., Schuster, S.C., Sun, Y., Talbot, S.L., Qi, J., Ratan, A., Tomsho, L.P., Kasson, L., Zeyl, E., Aars, J., Miller, W., Ingólfsson, Ó., Bachmann, L. \& Wiig, Ø. (2010). Complete mitochondrial genome of a Pleistocene jawbone unveils the origin of polar bear. P. Natl. Acad. Sci. USA 107, 5053-5057.

Liu, S., Lorenzen, E.D., Fumagalli, M., Li, B., Harris, K., Xiong, Z., Zhou, L., Korneliussen, T.S., Somel, M., Babbitt, C., Wray, G., Li, J., He, W., Wang, Z., Fu, W., Xiang, X., Morgan, C.C., Doherty, A., O’Connell, M.J., McInerney, J.O., Born, E.W., Dalén, L., Dietz, R., Orlando, L., Sonne, C., Zhang, G., Nielsen, R., Willerslev, E. \& Wang, J. (2014). Population genomics reveal recent speciation and rapid evolutionary adaptation in polar bears. Cell 157, 785-794.

Malenfant, R.M., Coltman, D.W. \& Davis, C.S. (2015). Design of a 9K illumina BeadChip for polar bears (Ursus maritimus) from RAD and transcriptome sequencing. Mol. Ecol. Resour. 15, 587-600.

Mauritzen, M., Derocher, A.E., Pavlova, O. \& Wiig, Ø. (2003). Female polar bears, Ursus maritimus, on the Barents Sea drift ice: walking the treadmill. Anim. Behav. 66, 107-113.

McLellan, B.N., Servheen, C. \& Huber, D. (IUCN SSC Bear Specialist Group) (2008). Ursus arctos. The IUCN Red List of Threatened Species 2008, e.T41688A10513490.

Miller, J.M., Poissant, J., Hogg, J.T. \& Coltman, D.W. (2012a). Genomic consequences of genetic rescue in an insular population of bighorn sheep (Ovis canadensis). Mol. Ecol. 21, 1583-1596.

Miller, W., Schuster, S.C., Welch, A.J., Ratan, A., BedoyaReina, O.C., Zhao, F., Kim, H.L., Burhans, R.C., Drautz, D.I., Wittekindt, N.E., Tomsho, L.P., Ibarra-Laclette, E., 
Herrera-Estrella, L., Peacock, E., Farley, S., Sage, G.K., Rode, K., Obbard, M., Montiel, R., Bachmann, L., Ingólfsson, Ó., Aars, J., Mailund, T., Wiig, Ø., Talbot, S.L. \& Lindqvist, C. (2012b). Polar and brown bear genomes reveal ancient admixture and demographic footprints of past climate change. P. Natl. Acad. Sci. USA 109, E2382-E2390.

Molnár, P.K., Derocher, A.E., Thiemann, G.W. \& Lewis, M.A. (2010). Predicting survival, reproduction and abundance of polar bears under climate change. Biol. Conserv. 143, 1612-1622.

Morin, P.A., Manaster, C., Mesnick, S.L. \& Holland, R. (2009). Normalization and binning of historical and multisource microsatellite data: overcoming the problems of allele size shift with allelogram. Mol. Ecol. Resour. 9, 1451-1455.

Nei, M., Maruyama, T. \& Chakraborty, R. (1975). The bottleneck effect and genetic variability in populations. Evolution 29, 1-10.

Norén, K., Carmichael, L., Dalén, L., Hersteinsson, P., Samelius, G., Fuglei, E., Kapel, C.M.O., Menyushina, I., Strobeck, C. \& Angerbjörn, A. (2011). Arctic fox Vulpes lagopus population structure: circumpolar patterns and processes. Oikos 120, 873-885.

Obbard, M.E., Cattet, M.R.L., Moody, T., Walton, L.R., Potter, D., Inglis, J. and Chenier, C. (2006). Temporal trends in the body condition of Southern Hudson Bay polar bears. Climate Change Research Information Note - Ontario Forest Research Institute 3, 1-8.

Obbard, M., Thiemann, G., Peacock, E. and DeBruyn, T.D. (2010). Polar bears: proceedings of the 15th working meeting of the IUCN/SSC Polar Bear Specialist Group, Copenhagen, Denmark, 29 June-3 July 2009. Gland and Cambridge: IUCN.

Overland, J.E. \& Wang, M. (2013). When will the summer Arctic be nearly sea ice free? Geophys. Res. Lett. 40, $2097-$ 2101.

Paetkau, D. \& Strobeck, C. (1994). Microsatellite analysis of genetic variation in black bear populations. Mol. Ecol. 3, 489-495.

Paetkau, D., Calvert, W., Stirling, I. \& Strobeck, C. (1995). Microsatellite analysis of population structure in Canadian polar bears. Mol. Ecol. 4, 347-354.

Paetkau, D., Shields, G.F. \& Strobeck, C. (1998). Gene flow between insular, coastal and interior populations of brown bears in Alaska. Mol. Ecol. 7, 1283-1292.

Paetkau, D., Amstrup, S.C., Born, E.W., Calvert, W., Derocher, A.E., Garner, G.W., Messier, F., Stirling, I., Taylor, M.K., Wiig, Ø. \& Strobeck, C. (1999). Genetic structure of the world's polar bear populations. Mol. Ecol. 8, 1571-1584.

Palstra, F.P. \& Ruzzante, D.E. (2008). Genetic estimates of contemporary effective population size: what can they tell us about the importance of genetic stochasticity for wild population persistence? Mol. Ecol. 17, 3428-3447.
Peacock, E., Sonsthagen, S.A., Obbard, M.E., Boltunov, A., Regehr, E.V., Ovsyanikov, N., Aars, J., Atkinson, S.N., Sage, G.K., Hope, A.G., Zeyl, E., Bachmann, L., Ehrich, D., Scribner, K.T., Amstrup, S.C., Belikov, S., Born, E.W., Derocher, A.E., Stirling, I., Taylor, M.K., Wiig, Ø., Paetkau, D. \& Talbot, S.L. (2015). Implications of the Circumpolar Genetic Structure of Polar Bears for Their Conservation in a Rapidly Warming Arctic. PLOS ONE 10, e112021.

Peakall, R. \& Smouse, P.E. (2006). genalex 6: genetic analysis in Excel. Population genetic software for teaching and research. Mol. Ecol. Notes 6, 288-295.

Peakall, R. \& Smouse, P.E. (2012). GenAlEx 6.5: genetic analysis in Excel. Population genetic software for teaching and research — an update. Bioinformatics 28, 2537-2539.

Perovich, D.K., Tucker, W.B. \& Krishfield, R.A. (1989). Oceanic heat flux in the Fram Strait measured by a drifting buoy. Geophys. Res. Lett. 16, 995-998.

Post, E., Bhatt, U.S., Bitz, C.M., Brodie, J.F., Fulton, T.L., Hebblewhite, M., Kerby, J., Kutz, S.J., Stirling, I. \& Walker, D.A. (2013). Ecological Consequences of Sea-Ice Decline. Science 341, 519-524.

Pritchard, J.K., Stephens, M. \& Donnelly, P. (2000). Inference of Population Structure Using Multilocus Genotype Data. Genetics 155, 945-959.

R Core Team (2015). R: A language and environment for statistical computing. Vienna, Austria: R Foundation for Statistical Computing. Available at: http://www. R-project.org.

Reed, D.H. \& Frankham, R. (2003). Correlation between Fitness and Genetic Diversity. Conserv. Biol. 17, 230-237.

Rode, K.D., Amstrup, S.C. \& Regehr, E.V. (2010). Reduced body size and cub recruitment in polar bears associated with sea ice decline. Ecol. Appl. 20, 768-782.

Rode, K.D., Peacock, E., Taylor, M., Stirling, I., Born, E.W., Laidre, K.L. \& Wiig, Ø. (2012). A tale of two polar bear populations: ice habitat, harvest, and body condition. Popul. Ecol. 54, 3-18.

Sahanatien, V. \& Derocher, A.E. (2012). Monitoring sea ice habitat fragmentation for polar bear conservation. Anim. Conserv. 15, 397-406.

Stirling, I., Lunn, N.J. \& Iacozza, J. (1999). Long-term trends in the population ecology of polar bears in Western Hudson Bay in relation to climatic change. Arctic 52, 294-306.

Vetter, W., Gall, V. \& Skírnisson, K. (2015). Polyhalogenated compounds (PCBs, chlordanes, HCB and BFRs) in four polar bears (Ursus maritimus) that swam malnourished from East Greenland to Iceland. Sci. Total Environ. 533, 290-296.

Vilà, C., Sundqvist, A.-K., Flagstad, Ø., Seddon, J., Björnerfeldt, S.B., Kojola, I., Casulli, A., Sand, H., Wabakken, P. \& Ellegren, H. (2003). Rescue of a severely bottlenecked wolf (Canis lupus) population by a single immigrant. P. Roy. Soc. Lond. B Bio. 270, 91-97. 
Vongraven, D., Aars, J., Amstrup, S., Atkinson, S.N., Belikov, S., Born, E.W., DeBruyn, T.D., Derocher, A.E., Durner, G., Gill, M., Lunn, N., Obbard, M.E., Omelak, J., Ovsyanikov, N., Peacock, E., Richardson, E., Sahanatien, V., Stirling, I. \& Wiig, Ø. (2012). A circumpolar monitoring framework for polar bears. Ursus 23, 1-66.

Wiig, Ø., Amstrup, S., Atwood, T., Laidre, K., Lunn, N., Obbard, M., Regehr, E. \& Thiemann, G. (2015). Ursus maritimus. The IUCN Red List of Threatened Species 2015, e.T22823A14871490.

\section{Supporting information}

Additional Supporting Information may be found in the online version of this article at the publisher's web-site:

Appendix S1. Further details on analyses, additional results, supplementary figures and tables.
Fig. S1. Maximum clade credibility tree based on a 681 bp fragment of the mt control region in 84 polar bears.

Fig. S2. SAMOVA results for population structuring in polar bears, based on mtDNA control region sequences.

Fig. S3. Median joining network of genetic variation at a $470 \mathrm{bp}$ fragment of the mitochondrial control region in 169 polar bears.

Table S1. Geographic origin, sequence information and subpopulation assignment of all individuals analyzed in this study. Table S2. Primers (in $5^{\prime}$ to $3^{\prime}$ orientation) and amplification conditions of nuclear and mitochondrial loci.

Table S3. Comparison of genetic variability by locus per study area.

Table S4. Pairwise genetic differentiation among subpopulations. Appendix S2. Y-linked SNP and microsatellite allele size data.

Appendix S3. Microsatellite allele sizes for 23 autosomal microsatellite markers. 